\title{
PERSPECTIVES FOR KOSOVO'S ACCESSION TO THE EU
}

Keywords: Kosovo, independence, Serbia, Western Balkans.

\begin{abstract}
Kosovo, the smallest country in Europe, over 10 years after declaring its independence, still remains outside of the European Union. As one of the countries of former Yugoslavia, it benefitted from the process of European integration, yet compared to neighbouring Western Balkan countries it is at an early stage of stabilisation and association process. The paper points to the main problems that Kosovo is facing, both at the internal and external level, in the face of the accession process and future membership in the European Union.
\end{abstract}

\section{INTRODUCTION}

Kosovo's current borders were established after World War II when it became Serbia's autonomous province within the Socialist Federal Republic of Yugoslavia. It needs to be remembered that Serbia and Kosovo have been connected with each other since the Middle Ages, and the conflict in this region dates back to the First Balkan War when Kosovo became part of Serbia. This is when brutal Serbianisation of Albanians living there occurred, aiming at increasing the Serbian population in this region (Sierpień, 2009). The breakthrough in Kosovo's status occurred in 1974 when the reform of the Yugoslavian con-

1 Aleksandra Raba-Schulze, PhD student at the University of Szczecin at the Faculty of Humanities on the Institute of Political Science and European Studies. ORCID ID: 0000-00034847-6131 
stitution gave Kosovo greater autonomy, thus making it possible for Kosovo to establish its own judiciary, assembly and its own administration. The new constitution also granted Kosovo the right to veto in all matters that concerned the province and ensured autonomy in relations to Serbia which in practice equaled independence as a separate republic even though this region did not have a republican status (Refworld, 2003). It is worth nothing that Josip Broza Tito was Yugoslavia's leader at the time and under his rule the multiethnic society coexisted in peace (Grabowska, 2016, p. 402) and all nationality-related conflicts were carefully concealed. A change in the political landscape and increased tension occurred after his death, when Slobodan Milošević became the head of the nationalistic Serbian government. He used the fact that Kosovo had historical and cultural significance for Serbia that perceived it as an integral part of its territory. He led to the reduction of Kosovo's competences by submitting Serbian courts and police to supervision in order to revoke Kosovo's independence in March 1989 (Jagiełło - Szostak, 2016, p. 132).

After the collapse of the SFRY in the 1990s the disintegration process also included Kosovo where growing ethnic conflicts and repressions applied by the Serbian government lead to the outbreak of war between the Kosovo Liberation Army and Serbian law enforcement agencies and the total breakdown of the rule of law. All international attempts to solve the conflict failed which is why in March 1999 NATO bombarded the Serbian armed forces wanting to make them to retreat from Kosovo (Special Report, 2012, p. 8). NATO's attack on Yugoslavia placed international relations on edge, dividing states into supporters and opponents of these activities (Bujwid -Kurek, 2008, p. 205).

After the 1999 crisis and NATO's intervention, the UN Security Council passed resolution 1244/00 transforming Kosovo into a UN-supervised territory. The resolution did not address Kosovo's future status, it granted Kosovo autonomy within the Federal Republic of Yugoslavia (Szeląg, 2013, p. 231). Pursuant to the resolution, the United Nations Interim Administration Mission in Kosovo (UNMIK) was established. The UNMIK's primary task was to guarantee Kosovo's interim administration to bring about the country's considerate autonomy. The Security Council vested administrative, legislative and judicial powers in the UNMIK. The constitutional framework established by the UNMIK in 2003 allowed gradual transfer of competences to interim institutions of autonomous administrations, though agreement regarding Kosovo's status 
has still not been reached. Wanting to break this deadlock, the UN SecretaryGeneral commissioned the UN Special Envoy Martti Ahtisaari to examine the possibilities of agreement as regards Kosovo's status. In 2007, after extensive consultations with all interested parties, Ahtisaari presented the "Comprehensive Proposal for the Kosovo Status Settlement", also known as Ahtisaari's plan, in which he proposed "supervised independence" of Kosovo (Derks, Price, 2010, p. 4), which meant a definite end to Serbia's control over the province (Domachowska, 2017, p. 201). Although Serbia rejected Ahtisaari's plan and Russia did not allow the UN Security Council to back it, two key proposals were implemented. Firstly, "the EU rule of law mission in Kosovo" (EULEX) was established, whose objectives were monitoring, mentoring, advising, providing support to the Belgrade-Pristina dialogue, and prosecuting and adjudicating selected criminal, civil and constitutional cases (European Council, 2018). Secondly, states recognizing Kosovo's independence established an International Civilian Office (ICO) which acted as a guarantor of respecting the rights of the Serbian minority and the Head of the ICO was given the authority to annul or cancel resolutions adopted by Kosovo authorities (Special Report, 2012, p. 9).

In 2008, when it became clear that reaching agreement on the Kosovo status was impossible, Kosovo unilaterally declared its independence from Serbia, thus becoming the newest country of Europe. Kosovo's independence was recognized by the United States and part of the European Union states, while Serbia supported by the allied Russia did not recognize Kosovo's independence and neither did the majority of ethnic Serbs. Kosovo's independence was also recognized by: Spain, Romania, Greece and Slovakia. In needs to be noted that these are the countries that struggle with issues relating to ethnic minorities (Zając, 2015, p. 99). Moreover, Kosovo is still effectively blocked by Russia and Serbia in the issue of membership in the CoE, the OSCE and the UN (JagiełłoSzostak, 2016, p. 140). Nevertheless, Kosovo joined the International Monetary Fund of the World Bank in 2009, the European Bank for Reconstruction and Developmentin 2012 and the Council of Europe Development Bank in 2013. Kosovo also joined the Venice Commission of the Council of Europe and the International Olympic Committee in 2014 (Theodora, 2018).

The European Union adapted its pre-accession policy supporting the Western Balkan countries in their integration process. Since the end of the 
conflict in 1999 Kosovo has made progress in a number of fields, still remaining though at an early stage of the accession process. The paper presents the perspective of Kosovo's accession to European structures and the challenges this country is facing in the process. The paper is an attempt to answer the question of what current problems - both internal and external - are hindering Kosovo's progress on its way to further integration.

\section{KOSOVO - EUROPEAN UNION}

The independence declared by Kosovo in February 2008 implemented a new chapter in the relations between Kosovo and the European Union. It needs to be stressed, though, that the European Union together with the member states is playing a significant role in the process of development at the social and economic as well as institutional level. Since 1999 Kosovo has received financial aid in the total of EUR 2.3 billion, allocated to projects covering public infrastructure, including roads, hospitals and projects covering support for human rights, education, farms and healthcare. Kosovo's priority since declaring its independence has been obtaining the European Union membership. It needs to be highlighted that today Kosovo has the status of a potential candidate.

Without a doubt, during recent years Kosovo has made progress towards European integration, and the most recent achievement was signing the Stabilisation and Association Agreement with the European Union on 27 October 2015. It needs to be remembered that due to the specific status of Kosovo, the European Union was somehow forced to find an alternative mechanism of integration guaranteeing Kosovo its participation in the SAP. As a result, in November 2002, a special mechanism for the European Commission regular contact and consultation with the UNMIK and PISG was created exclusively for Kosovo, i.e. the Stabilisation and Association Process Tracking Mechanism thanks to which the European Union monitored Kosovo's progress under the SAP relating to the use of received financial resources and the implementation of required economic and political reforms (Filipowicz, 2011, p. 104).

The Stabilisation and Association Agreement signed in 2015 is perceived as Kosovo's first key step in the process of accession to the European Union. It establishes for the first time contractual relations and mutual obligations 
between the Union and Kosovo. Its objective is to help Kosovo in the implementation of reforms tailored to EU requirements as well as to create trade and investment opportunities. Other provisions also include political dialogue and cooperation in various sectors. The Agreement respects key democratic principles and as Federica Mogherini emphasized, it is an important contribution to peace, stability and prosperity in Kosovo and the entire region (Parlementaire Monitor, 2016). Kosovo's non-normative status needs to be noted here again, creating a case in the history of enlargement of the European Union. Comparing the Stabilisation and Association Agreements that the EU signed with other Western Balkan countries, Kosovo's SAA features two distinctive differences. First, due to non-recognition of Kosovo's independence by five member states the SAA with Kosovo was signed "on behalf of the European Union", which was possible as the agreement was signed after the entry into force of the Lisbon Treaty which gave the European Union a legal personality (European Policy Centre, 2017, p. 8). Second, the agreement concerns Kosovo with "an asterisk", which means that the European Union remains in neutral relations with Kosovo. It needs to be remembered that when signing the Stabilisation and Association Agreement Kosovo agreed to implement specified reforms in a designated time. The European Reform Agenda (ERA) was launched on 17 May 20016 and suggested that Kosovo carry out a number of comprehensive reforms. The main areas of reform include the rule of law and good governance, competitiveness and investment climate as well as employment and education. The European Reform Agenda should not be perceived as a new catalogue of requirements set by the EU, but a list of priorities (Merja, 2017, p. 3) which should be implemented in order for Kosovo to confirm the implementation of European standards.

Table 1. Timeline of Kosovo's integration with the European Union

\begin{tabular}{|l|l|}
\hline $01-11-2000$ & $\begin{array}{l}\text { Zagreb Summit launches Stabilisation and Association Process (SAP) for } 5 \text { countries of south-eastern Eu- } \\
\text { rope }\end{array}$ \\
\hline $01-04-2005$ & Commission adopts a communication on “A European Future for Kosovo" \\
\hline $01-02-2006$ & UN Special Envoy launches status negotiations \\
\hline $04-02-2008$ & Council adopts Joint Action establishing EU Rule of Law mission in Kosovo EULEX \\
\hline $18-02-2008$ & $\begin{array}{l}\text { Council acknowledges Kosovo's declaration of independence, underlines EU conviction that Kosovo is a sui } \\
\text { generis case. }\end{array}$ \\
\hline $15-06-2008$ & Kosovo adopts its Constitution \\
\hline $09-12-2008$ & EULEX becomes operational \\
\hline $14-10-2009$ & Commission issues communication “Kosovo-Fulfilling its European Perspective" \\
\hline
\end{tabular}




\begin{tabular}{|c|c|}
\hline $22-07-2010$ & The International Court of Justice issues advisory opinion on Kosovo's declaration of independence \\
\hline 08-03-2011 & Following a UN General Assembly Resolution the Kosovo-Serbia technical dialogue begins \\
\hline 19-01-2012 & Commission launches the visa liberalisation dialogue with Kosovo \\
\hline $30-05-2015$ & Commission launches the Structured Dialogue on the Rule of Law \\
\hline 14-06-2012 & Commission issues Kosovo's visa liberalisation roadmap \\
\hline $\begin{array}{l}10-09-2012 \\
10-10-2012\end{array}$ & $\begin{array}{l}\text { Kosovo declares the end of supervised independence } \\
\text { Commission issues its feasibility study for a Stabilisation and Association Agreement between the EU and } \\
\text { Kosovo }\end{array}$ \\
\hline 19-10-2012 & High-level dialogue between Kosovo and Serbia as facilitated by HRVP Ashton begins. \\
\hline $25-07-2014$ & $\begin{array}{l}\text { The EU and Kosovo chief negotiators initialled the Stabilisation and Association Agreement between the } \\
\text { EU and Kosovo in Brussels. }\end{array}$ \\
\hline $01-04-2016$ & he Stabilisation and Association Agreement between the EU and Kosovo enters into force. \\
\hline
\end{tabular}

Source: https://ec.europa.eu/neighbourhood-enlargement/countries/detailed-country-information/kosovo_en.

\section{DETERMINANTS OF THE PROCESS OF KOSOVO'S ACCESSION TO THE EU}

Kosovo's current progress on its path to integration with the European Union depends on factors at an internal and external level. In the internal categories, the process of integration with the European Union is related to the country's economic situation which at the moment admittedly is an obstacle to Kosovo's membership in the European Union. A decade after declaring its independence Kosovo remains the poorest country in Europe with the GDP per capita at USD 10,400 in 2017 (Theodora, 2018). The poverty level is regionally differentiated, the elderly and households run by single women and households with disabled persons are in the most difficult situation (Marcinkowska, 2016, p. 186). The high level of poverty is also related to extensive corruption and a high unemployment rate at $33 \%$, and at $60 \%$ among young people. Youth's high unemployment in a country where the average age is 26 causes emigration which drives informal economy. The problem also lies in low-income households which results from lack of technical knowledge and limited mechanization (Theodora, 2018). Aging machinery and equipment are also a reason for the decline in the production of minerals and metals, which where once the backbone of Kosovo's industry (Factbook, 2018).

Kosovo features lower work costs than the rest of the region, however corruption is still at a high level and unsystematic electricity supply discourages potential investors. In a report published in 2017 by Transparency International 
Kosovo sat on the $85^{\text {th }}$ position among the 180 investigated countries, obtaining 39 points out of 100 (Travers, 2018). A Wall Street Journal reporter pointed out that in the centre of Pristina apart from the visible poverty one can see luxury shops or teenagers driving luxury cars. This displayed affluence comes from organized crime and constitutes informal economy, especially in North Kosovo (Haziri, 2017, p. 4). Kosovo's economic backwardness is among others a result of the war with Serbia, a country from which Kosovo gained independence over 10 years ago, but on which it still remains heavily economically dependent. Official data shows that in the scale of the year Kosovo buys EUR 450 million worth of merchandise from Serbia, whereas it sells only worth of EUR 48 million (Statistical Yearbook, 2017, p. 145). By doing so, through trade alone Kosovo gives back EUR 400 million every year to Serbia. Kosovo's economic relations with Serbia are much stronger than those with Albania. Today Kosovo imports three times more from Serbia than from Albania, and it is a gap that apart from an economic factor is a proof of the two countries' failure in their economic integration. Moreover, the economic cooperation of both countries is hindered by unresolved issues relating to free movement of people and goods. Certificates have still not been harmonized and customs procedures remain unresolved. More than $80 \%$ of Kosovan companies point out that goods transit is the main obstacle in cooperation with Serbia. The companies point out that goods with the "Republic of Kosovo" seal cannot go through an administrative crossing which forces transport of goods via Albania. Thus, traders bear additional costs in the form of double fees for excise duty. Difficulties also occur in the functioning of the payment movement since foreign currencies must be converted into dinars, which is a considerable expense for small enterprises (Sadrzaj, 2018).

Kosovo's European integration does not only involve economic reforms, but also good neighbourly relations and regional cooperation. As already mentioned, Serbia refused to recognize Kosovo's independence and since 2011 both countries have avoided direct contact. The technical dialogue between Pristina and Belgrade was initiated with the participation of the European Union in March 2011. The talks focused on technical issues and the agreements made concerned, among others, mutual document recognition, water economy, protection of borders, trade exchange (Marcinkowska, 2016, p. 70). It is worth noting that despite its name the dialogue had a highly political nature as all discussed issues also involved the aspect relating to Kosovo's status (Lehne, 
2012, p. 8). A milestone in the normalization of relations between Belgrade and Pristina was the agreement made between the governments of both countries on 19 April 2013. The key provision of the 15-point agreement was the creation of the Association of Serb majority municipalities in North Kosovo. It is worth emphasizing that the leaders of both countries agreed not to come in the other's way in pursuing membership in the European Union. It needs to be stressed that establishing the Association of Serb majority municipalities is an obligation that Kosovo accepted in the mutual dialogue. The implementation of the Brussels agreement is running slowly since only on 4 April 2018 in Kosovo was the team tasked with drafting the statute of the Association of Serb majority municipalities drawn up. Speeding up the implementation of the agreement is an urgent necessity for Kosovo's future which in its pursuit of integration with European structures needs to appear as a reliable country that fulfills the agreement's provisions.

Despite the ongoing talks under the auspices of the European Union concerning normalization of relations between Kosovo and Serbia, tension leading to escalation of conflict between these countries is still observed. Kosovan Serbs for years have been a group that is against Kosovan countryhood (Pawłowski, 2016, p. 115). At the moment, they also reject integration with Kosovo and want to maintain strict ties with Serbia and its administration (Robinson, 2018). Currently, Serbs oppose the creation of Kosovo Armed Forces since it would mean confirming Kosovo's independence which they do not recognize. The government in Belgrade is of the view that it is impossible to create Kosovo's army due to provisions in the UN resolution 1244 as well as due to Kosovan constitution whose provisions make it possible for opposition to block any laws on this issue. Nevertheless, the parliament in Pristina on 18 October submitted three draft bills which are a basis for transforming Kosovo Security Force into a regular army, and thus the need to amend the constitution was avoided, in order to legally establish the Armed Forces (RTE, 2018). In accordance with the information announced by Kosovo's authorities, the Kosovo Armed Force was to be composed of 8,000 people of which 3,000 is to form a reserve. The USA and Turkey are to be the main suppliers of equipment and arms. This involves both financial and political support that these countries are providing to Kosovo. Moscow believes that the establishment of the Kosovo army will further exacerbate the tense situation between the two states and 
claims that the new military formation would be a destabilizing factor for the entire European continent. Kosovan authorities intend to prove that they can cope with the country's internal problems independently. The security force is being promoted as a multiethnic structure responsible for all citizens, which is to affect the reliability of this entity on the side of international institutions.

The worsening of the relations between Kosovo and Serbia also occurred after the assassination of a popular Serbian politiciann from Kosovo, Oliver Ivanović, who was shot on 16 January 2018 in northern Mitrovica. Serbia called the assassination of the politician as an attack on the entire nation and Russia assessed the assassination as a terrorist act. It is worth remembering here that in 2016 Ivanović was found guilty of crimes against ethnic Albanians in 19992000 by the international court in North Kosovo, where the conviction was annulled and the case transferred for reconsideration. Ivanović never pleaded guilty stating that the prosecutor's actions were politically motivated. It should be emphasized that wanting to strengthen its credibility as a partner of the European Union Kosovo needs to account for its infamous past, in particular respect the commitments made regarding the operation of the Kosovo Special Court. The Special Court with its seat in The Hague set up to examine war crimes committed by the Kosovo Liberation Army was established by Kosovo's Parliament in 2015. The Court officially began its activities in July 2017 where first indictments will be filed in 2019. At the moment, data collected by the Special Investigative Task Force, which includes approximately 70 thousand documents, is being verified (Gazetaexpress, 2018). The idea of creating the Special Court was backed by the Democratic Party of Kosovo (DPK), which now supports the abolition of this institution. Despite Kosovo's Prime Minister's assurance that the Special Court shall not be abolished, it needs to be remembered that at the end of December 201743 MPs took the initiative regarding its dissolution by signing a petition which called for a vote on a law that was supposed to repeal the Special Court. Taking efforts aiming at abolishing the Court questions Kosovo's credibility as a partner of the European Union and may affect the process of recognizing Kosovo in the international arena.

The escalation of tensions was caused in January by a train sent from Mitrovica to North Kosovo. The said train was painted in Serbian national colours but most of all it bore writing, translated into 21 languages (including Albanian), saying "Kosovo is Serbia". The train was stopped at an administrative 
crossing with Kosovo and turned back to Belgrade by the decision of Prime Minister Aleksandar Vučić who justified his decision with "saving human life and preventing large-scale conflicts". Allegedly, the Prime Minister was to receive information about explosives placed on the train tracks already on the Kosovan side of the train's route.

Tensions between Kosovo and Serbia are a serious obstacle in the integration of the Western Balkans under one block and contribute to a lack of stability in this region. The on-going deadlock results in none of the countries having a real chance for accession to the European Union, which consideres "normalization of relations" as a preliminary requirement for membership. Belgrade and Pristina are still carrying out dialogue on the normalization of relations and recently there have been signals that both governments, in seeking agreement, may negotiate in terms of changing borders. Reaching agreement on the issue of borders would mean the final recognition of Kosovo's independence by Serbia and remove a fundamental obstacle for both countries' accession to European structures. It needs to be stressed that this information causes an increase in tensions in Kosovo on the president-prime minister line. The great part of the opposition led by the ruling party categorically opposes this idea. According to observers, opponents of changing borders prefer maintaining the status quo in today's relations with Serbia since they see more benefits in it. An argument for retaining current borders is the fact that valuable natural deposits are under the control of the government in Kosovo and political goals such as achieving visa free movement with the European Union are at the last stage of proceedings in the European Parliament. One needs to note in particular that the future change in the borders can set a precedent which Russia can use to legalize its claims towards Crimea, Transnistria, Abkhazia and South Ossetia. The change of borders between Kosovo and Serbia may also fuel fights for redemarcation of borders in other parts of Europe.

\section{KOSOVO'S PROGRESS ON ITS PATH TOWARDS THE INTEGRATION WITH THE EUROPEAN UNION}

A concrete example of Kosovo's commitment to good neighbourly relations was the ratification of the border demarcation agreement with Montenegro on 21 
March 2018. The ratification of the agreement confirmed both countries' 2015 obligations to sign a border deal. It needs to be remembered that the ratification of the demarcation agreement took place after numerous postponements, and signing it is a step towards Kosovo receiving visa free movement in the European Union.

Table 2. Timeline of ratification of the border demarcation agreement with Montenegro

\begin{tabular}{|l|l|}
\hline November 2012 & \multicolumn{1}{|c|}{ Launching consultations on signing an international agreement on border demarcation. } \\
\hline August 2015 & Signing the agreement in Vienna. \\
\hline October 2015 & Opposition parties use tear gas in parliament in condemnation of the agreement \\
\hline August 2016 & Kosovo government adopts draft law on border demarcation \\
\hline September 2016 & $\begin{array}{l}\text { Citizens' protests during which Prime Minister Isa Mustafa preliminarily sends the agreement for a vote } \\
\text { in parliament but then withdraws it }\end{array}$ \\
\hline May 2017 & Fall of Kosovo government \\
\hline December 2017 & $\begin{array}{l}\text { New government backs re-assessment of the border deal, according to the new committee the deal is } \\
\text { unfavourable for Kosovo }\end{array}$ \\
\hline February 2018 & $\begin{array}{l}\text { Presidents of both countries present a statement in which they declare the creation of a joint working } \\
\text { body }\end{array}$ \\
\hline February 2018 & First attempt to ratify the agreement in parliament fails \\
\hline March 2018 & $\begin{array}{l}\text { Assembly fails to proceed to a vote on the border agreement after the government fails to stack up the } \\
\text { necessary numbers, two-third of all votes, 80 out of 120 MPs. }\end{array}$ \\
\hline
\end{tabular}

Source: based on http://www.balkaninsight.com/en/article/xx-kosovo-parliament-approvesmontenegro-border-deal-03-21-2018.

It also needs to be highlighted that the European Commission in its July 2018 report concluded that it is satisfied with the agreement on the demarcation of the border with Montenegro. The Commission pointed out that in terms of security and migration Kosovo set up legal framework concerning managing migrations, including establishing new laws on foreigners and asylum. Kosovo has also made progress in the judiciary area and in the field of fighting organized crime, including improving legislation by introducing the law on preventing conflict of interest the aim of which is ensuring transparency and correctness of public administration processes (EC Report, 2018, p. 7) and the law on state prosecutor which is to ensure the increase of the number of prosecutors responsible for proceedings in cases of high-level corruption and organized crime (EC Report, 2018, p. 7). 


\section{CONCLUSION}

Integration with the European Union has undoubtedly been Kosovo's key target since declaring its independence on 17 February 2008. The neutral status of the European Union towards Kosovo's status shows Kosovo's complex situation on the international arena. Over a decade after declaring its independence, five countries still do not recognize its independence and it is one of the main threats to European aspirations of Europe's youngest country. Ending the conflict between Belgrade and Pristina could help countries that have not recognized Kosovo's independence in taking their final decision. The dialogue between Kosovo and Serbia moderated by the European Union has eliminated some administrative problems, making citizens' lives easier, yet the aggressive rhetoric between these countries is still present. Settling the dispute may speed up European integration of both Kosovo and Serbia. One needs to remember that the normalization of relations is the requirement set by the European Union. Unresolved relations with Serbia make it impossible for Kosovo to participate in a number of institutions, including the UN. Apart from dialogue and agreement with Serbia, Kosovo needs to strengthen its economy and rule of law. Corruption poses a threat to stability of state institutions and blocks economic progress discouraging potential investors, which restricts the country's economic development. The European Commission declared 2018 the Western Balkans' year of opportunity at the same time calling on all nations to use the opportunity for a European future. It needs to be emphasized that the European Union will not compromise on the issue of membership, which is why Kosovo should take effort to fulfill the adopted obligations and to implement reforms so as to build its credibility as a partner of the European Union. Despite the progress made, Kosovo's balance sheet is not favourable. The economic crisis, extensive unemployment and widespread corruption cause Kosovo to be still perceived as an unstable and poor state. In addition, the country is struggling to maintain stable state institutions, which is conducive to the spread of influence of criminal circles and deepening of social inequalities, which lead to a general dissatisfaction and frustration of the Kosovan people. 


\section{BIBLIOGRAPHY:}

ANNEXES to the REPORT FROM THE COMMISSION TO THE EUROPEAN PARLIAMENT AND THE COUNCIL Update on the implementation of the remaining benchmarks of the visa liberalisation roadmap by Kosovo*, as outlined in the fourth report on progress of 4 May 2016. Downloaded from: http:// ec.europa.eu/transparency/regdoc/rep/1/2018/DE/COM-2018-543-F1-DEANNEX-1-PART-1.PDF [access 10.10.2018].

Bujwid-Kurek, E. (2008). Państwa Pojugosłowiańskie. Kraków: Wydawnictwo Uniwersytetu Jagiellońskiego.

Derks, M, Price, M. (2010). The EU and Rule of Law Reform in Kosovo. Netherland Institute for Internacionale Relation.

Dessus, Z., Rexa, A., Merja,.A. (2017). Kosovo's EU candidate status: a goal within reach? European Policy Center.

Domachowska, A. B. (2017). Od reminiscencji do realizacji „wielkiej idei”? Działalność polityczna Albańczyków na Bałkanach na przełomie XX i XXI wieku. Toruń: Wydawnictwo Naukowe Uniwersytetu Mikołaja Kopernika.

Filipowicz, M. (ed.) (2011). Konflikty narodowe i europejskie aspiracje państw bałkańskich. Lublin: Instytut Europy Środkowo - Wschodniej.

Grabowska, K. (2016). Piętno casusu Kosowa. Świat idei i polityki, 15, pp. 386-417. Haziri, F (2017). Fighting organized crime in Kosovo. Concordiam.

http://ask.rks-gov.net/en/kosovo-agency-of-statistics/add-news/statistical-yearbook-of-the-republic-of-kosovo-for-2017.

http://www.psz.pl/116-bezpieczenstwo/przemyslaw-sierpien-kosowo-zarys-konfliktu-cz-i.

http://www.refworld.org/docid/3ae6a80c0.html.

https://borgenproject.org/kosovo-serbia-relations/.

https://prishtinainsight.com/kosovo-improves-ranking-transparency-international-corruption-index/.

https://theodora.com/wfbcurrent/kosovo/kosovo_economy.html.

https://www.consilium.europa.eu/en/press/press-releases/2018/06/08/eulex-koso-

vo-new-role-for-the-eu-rule-of-law-mission.

https://www.gazetaexpress.com/en/news/kosovo-war-crimes-court-to-file-firstindictments-in-2019-174226/.

https:/www.indexmundi.com/factbook/compare/serbia.kosovo/economy. https://www.parlementairemonitor.nl/9353000/1/j9vvij5epmj1ey0/vk2vfcmjaoy0? $\mathrm{ctx}=\mathrm{vg} 9$ pktppo $1 \mathrm{xz} \& \mathrm{v}=1 \& \mathrm{tab}=1 \&$ start_tab $0=220$.

https://www.rte.ie/news/2018/1019/1005194-kosovo-to-form-army/. 
Jagiełło, A. (ed.) (2016). Republika Serbii, Aspekty polityki wewnętrznej i międzynarodowej. Wrocław: Oficyna Wydawnicza ATUT.

Lehne, S. (2012). Kosovo and Serbia: Toward a normal relationship, Carnegie Endowment for International Peace.

Marcinkowska. P. (2016). Kosowo jako suwerenne państwo. Warszawa: Wydawnictwo Naukowe Scholar.

Merja, .A. (2017). A new ERA for Kosovo: Perspective on the European Reform Agenda. Group for legal and political studies, 1.

Pawłowski, K. (2016). Konflikt serbsko-albański w Kosowie w latach 1999-2014. Lublin: Wydawnictwo UMCS.

Special Report No 18/2012 - European Union assistance to Kosovo related to the rule of law, http://www.europarl.europa.eu/meetdocs/2009_2014/documents/ cont/dv/eca_sr182012_/eca_sr182012_en.pdf.

Szeląg, P. (2013). Od interwencji sojuszu północnoatlantyckiego do orzeczenia międzynarodowego trybunału sprawiedliwości - aktywność Organizacji Narodów Zjednoczonych w celu rozwiązania konfliktu w Kosowie. Problemy wspótczesnego prawa międzynarodowego, europejskiego i porównawczego, X.

Zając, P. (2015). Niepodległość Kosowa z perspektywy społecznych teorii stosunków międzynarodowych. Lublin: Wydawnictwo Uniwersytetu Marii Curie Skłodowskiej. 